\title{
Assessing the Effects of Length, Slope and Distance between Piles on the Bearing Capacity of a Pile Group under Axial Loading in Granular Soil
}

\author{
Alireza Firoozfar \\ Civil Engineering Dpt \\ University of Zanjan \\ Zanjan, Iran \\ firoozfari@ \\ znu.ac.ir
}

\author{
Arash Rostami \\ Civil Engineering Dpt \\ Islamic Azad \\ University Central \\ Tehran Branch, Iran \\ dr.arash.rostami@ \\ gmail.com
}

\author{
Hamid Ghaderi \\ Civil Engineering Dpt \\ Islamic Azad \\ University Maragheh \\ Branch \\ Maragheh, Iran \\ hamid_ghaderi2002@ \\ yahoo.com
}

\author{
Habib Zamani \\ Civil Engineering Dpt \\ University of Zanjan \\ Zanjan, Iran \\ zamanihabibi@ \\ yahoo.com
}

\author{
Ali Rostamkhani \\ Civil Engineering Dpt \\ Islamic Azad \\ University Zanjan \\ Branch \\ Zanjan, Iran \\ alirostamkhan1370@ \\ gmail.com
}

\begin{abstract}
Piles are usually made of steel, concrete, reinforced concrete or wood, used to enhance the ground's bearing capacity in order to enable the construction of deep foundations, also called pile foundations. However, the exact effect of the complex interaction between the piles and the surrounding soil has not adequately been investigated yet. Considering the increased application of the technique recently, further analysis is essential for achieving the highest economic and technical capacity. Using fewer piles or shorter piles and allowing greater distances between pile groups, results to reduced construction. However, other restrictions such as high groundwater level, bedrock depth and the limited size of the foundation are also to be considered. The issue of optimal pile layout is further investigated in the current paper employing Plaxis, a finite element software, for modeling purposes and considering axial loadings in granular soils. Results are shown and further discussed.
\end{abstract}

Keywords-pile; group; inclined; bearing capacity; Plaxis; model

\section{INTRODUCTION}

The use of piles in foundations is an issue that has gained increased interests recently, and research focuses on piles' axial or lateral behavior and the effects of intervals in groups, or on the effects of load distribution between the group piles, or lateral displacement of the group and the number of the piles in the groups, or on using inclined piles among pile groups which are under seismic loadings. In [1], authors investigated the effect of increasing the pile inclination angle in earthquake loadings. In [2], authors showed that by increasing the inclination angle of pile groups to a certain amount, displacements and bending moments at junction points of caps to the piles show considerable reduction [2]. In [3], genetic algorithm principals were used to optimize the length, location in the soil, cross section, material, types of installations and functions of the piles in order to reduce construction costs and significant reduction was recorded. In [4], some criteria for lateral bearing capacity of inclined piles were presented and it was concluded that the reason of the differences of lateral loading of positive and negative inclined piles is the reaction amount of mobilized soil on the surface of the earth. Thus, for inclined positive piles, soil reaction on the surface ground is zero, while this reaction for negative inclined piles is the maximum amount, and so the material of surface layer has extremely significant effect on loading capacity of inclined piles [4]. In [5], authors experimented on two groups with intervals of $0 / 9$ and $1 / 2$ meters and found that in the larger distances the bearing capacity encounters increase of $1 / 5$ to 2 times [5]. In [6], a few tests with inclined piles in clay soil were conducted. Lateral displacement of negative inclined piles under the lateral loads was lower in contrast with positive inclined piles [6]. In [7], authors showed that after the 1995 earthquake in Kobe port, quay wall with stands of inclined piles has experienced displacement of about $20 \mathrm{~cm}$ without any damage. In [8], numerical methods were employed and it was stated that the coefficient efficiency of the pile groups depends on piles' spaced intervals and that piles' coefficient efficiency increases with increasing their intervals. The evidence showed that one of the few walls that remained intact after the earthquake was a composite wall, which was supported by inclined piles, whereas a nearby wall supported on vertical piles was heavily damaged. In [9], authors studied the nonlinear behavior of inclined piles under lateral loads and presented a numerical model with finite elements. The results suggested that negative inclination may result to rapid healing under loading [9]. In [10], authors studied the inclined piles' behavior under lateral loads and showed that lateral displacement depends on the inclined pile's angle. In [11], authors showed that the negative inclined piles resistance is more than the resistance of positive inclined piles, under the affection of lateral loads. They also asserted that the lateral displacement of the double pile group consisted of a vertical pile and an inclined pile (positive or negative) is less than the displacement of double vertical pile groups. In [12], authors studied the vertical pile and single inclined pile's resistance 
under tensile loads. In these experiments, two piles with two different lengths were evaluated. Results showed that the tensile capacity of the piles would decrease with increasing the inclination angle of the pile, however piles inclination angle on the piles' tensile friction resistance is low. In [13], authors studied the frictional resistance of single verticals and inclined piles. This laboratory research was done on two types of steel piles with diameter of $76 \mathrm{~mm}$ and $38 \mathrm{~mm}$, in sand with relative density of $65 / 3 \%$. In order to calculate the ultimate strength of the pile, the load deformation curve was plotted, and a point where the slope of the graph charts were changed considered as the final amount of frictional resistance. Dividing the final resistance of the pile to the pile length, determined the ultimate amount of frictional resistance of per length unit as $\mathrm{f}_{\mathrm{s}}$. With increasing the $\mathrm{L} / \mathrm{D}$ of the frictional resistance, the length unit of $\mathrm{f}_{\mathrm{s}}$ increases until the crisis depth and after reaching this depth, increasing the resistance continues too slowly. In addition, by increasing the inclination angle of the vertical pile with friction resistance the unit length decreases. With increasing the inclination angle from zero to 30 degrees, the lateral resistance of the pile would be reduced [13].

\section{MODELING AND ASSESSING PILE GROUP BEHAVIOR IN GRANGULAR SOIL UNDER VERTICAL LOADS}

Computer modeling was used in order to evaluate the performance of the pile group. The method is that at first a group of $4 \times 4$ piles with diameters of 1 meter, length of 8 meters and intervals of 1 meter, placed in sandy soil under vertical load, was modeled by Plaxis 3D Foundation software. In this study, all the piles were assumed to have a constant diameter of 1 meter. Loading on the pile was done according to the wide loading manner. The load was increased gradually until the failure of the soil mass. In this way, the ultimate bearing capacity of the pile group was obtained. Then by changing the pile intervals to $1 / 5$ and 2 meters and changing the piles length to 10 and 12 meters, the ultimate loading capacity and logical relation of loading capacity variation in different models were being assessed. Then the model with the most loading capacity was selected and the amount of the increase or reduction of the bearing capacity was checked by Plaxis 2D, changing the relative angles of the vertical side. Plexis 2D was used due to Plaxis 3D being unable to correctly model the inclined piles. Finally, by evaluating the performance of different arrangements of the piles, the best pattern of pile groups under vertical loads in granular soils was obtained.

\section{A. Soil characteristics}

In this study, the soil was of the one layer kind (drainage sand) and the specifications are shown in Table I. The thickness of the soil layer was considered as 30 meters and water level was assumed as 13 meters underground.

\section{B. Characteristics of piles}

The piles considered in this study were concrete constant piles with diameters of 1 meter and specifications as shown in Table II. Concrete pile caps dimensions were $12 \times 12$ meters, their thickness was 1 and their specification profile was as the pile's specifications. In all models, size and thickness of the piles were kept constant and only intervals were changed. Confidence coefficient of the ultimate bearing capacity was calculated and assumed to be equal for all models. In all studied models the number of piles were 16 (pile groups of $4 \times 4$ ). Also after modeling the mentioned pile group in Plaxis, axial loading was applied widely on piles and the load increased until the failure of the soil. Then the ultimate bearing capacities of the pile groups were obtained.

TABLE I. SOIL CHARACTERISTICS IN MODELING THE PILE GROUPS.

\begin{tabular}{|c|c|c|}
\hline $17.6 \mathrm{kN} / \mathrm{m}^{3}$ & $\gamma_{\text {unsat }}$ & Dry Density \\
\hline $20 \mathrm{kN} / \mathrm{m}^{3}$ & $\gamma_{\text {sat }}$ & Wet Density \\
\hline $19000 \mathrm{kN} / \mathrm{m}^{2}$ & $\mathrm{E}$ & Elasticity Module (Young) \\
\hline 0.3 & $\mathrm{~V}$ & Poisson Ratio \\
\hline 0 & $\mathrm{C}$ & Adherence \\
\hline 23 Degree & $\Phi$ & Internal Friction Angle of Grains \\
\hline 0 & $\psi$ & Dilation Angle \\
\hline 1 & $\mathrm{R}_{\text {inter }}$ & Interaction Coefficient of Soil and Concrete \\
\hline 0.6 & $\mathrm{~K} 0$ & Lateral Pressure of the Soil \\
\hline
\end{tabular}

TABLE II. PILES SPECIFICATIONS

\begin{tabular}{|c|c|c|}
\hline $24 \mathrm{kN} / \mathrm{m}^{3}$ & $\gamma_{\text {unsat }}$ & Special Weight \\
\hline $29.2 \times 10^{6} \mathrm{kN} / \mathrm{m}^{2}$ & $\mathrm{E}$ & Elasticity Module (Young) \\
\hline 0.15 & $\mathrm{~V}$ & Poisson Ratio \\
\hline 1 & $\mathrm{R}_{\text {inter }}$ & Interaction Coefficient of Soil and Concrete \\
\hline
\end{tabular}

\section{Assising the effects of different lay outs}

In these models, piles' diameters were considered as 1 meter, piles' length were considered as 8,10 and 12 meters and piles' intervals were considered as $1,1 / 5$ and 2 meters. Modeling stills are shown in Figure 1. The results are summarized in Table III. By examining the bearing capacity between different pile groups, it was found that the pile groups with 10 meters length show the highest bearing capacity and among them piles with $1 / 5$ meters interval have the highest amount of bearing capacity (Figure 2). Therefore, examining the ratio between the piles length and intervals showed a logical connection. In models made with 8 and 12 meters, the highest ultimate bearing capacity was in the groups where their ratio of length to interval was 8 .

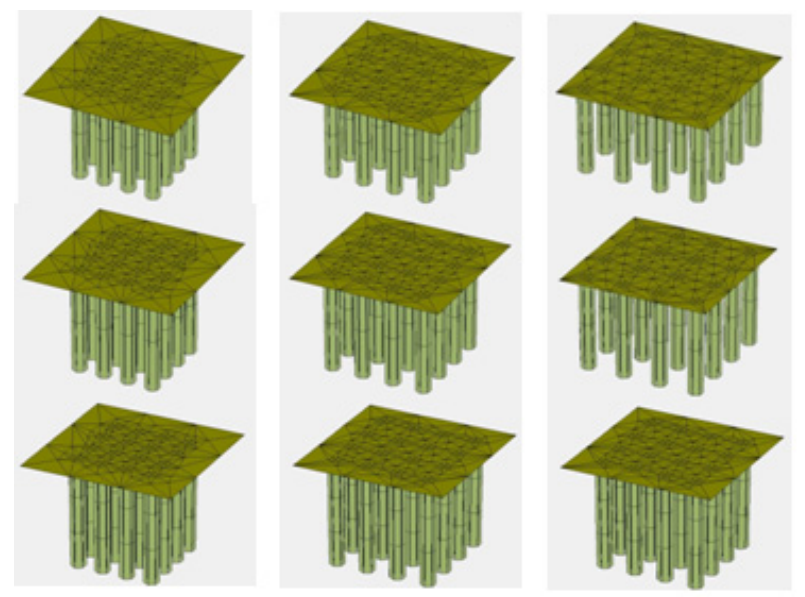

Fig. 1. Pile groups with diameter of 1 meter and length of 8,10 and 12 meters and intervals of $1,1 / 5$ and 2 meters. 
In order to verify this relationship in 10 meters models, a pile group at intervals of $1 / 25$ meters was modeled and the ultimate bearing capacity was acquired. The results showed that in models with 10 meters, the highest bearing capacity is in a model with length to interval ratio of 8 . The results of this model's loading are shown in Table IV. In order to verify the ratio of piles' length with bearing capacity a group of piles with length of 8 meters and intervals of $0 / 5$ meters was considered. After analyzing the results it was found that with increasing the ratio of the length to the interval, the bearing capacity is reduced. Therefore in the pile groups with length of 8 meters at different intervals, the highest capacity would be acquired in groups with a ratio of 8 . The results of this loading model are shown in Table V. Figure 3 shows the ultimate bearing capacity changes of pile groups in different intervals of 8,10 , and12 meters which they verify the mentioned relationship. Assessing the graphs show that in almost all of the models, the maximum bearing capacity is in ratio of 8 , and all figure charts are almost the same.

\section{EVALUATING THE EFFECTS OF SLOPE ON ULTIMATE BEARING CAPACITY}

The model which had the largest ultimate bearing capacity on the three dimensional analysis in a 4 row order was modeled with Plaxis $2 \mathrm{D}$ to calculate the ultimate bearing capacity. Then, the angles of lateral piles to vertical piles were varied, and the effects of ultimate bearing capacity of the pile group were checked. The characteristics of the soil, the pile and the pile head is assumed to be as the three dimensional model. In this model, the pile diameter was one meter, the lengths of the piles were 10 meters and the distance between piles was considered as $1 / 25$ meter. The changing angles of lateral piles considered as $0,15,30$ and 45 degrees. Modeling stills are shown in Figure 4. Results are shown in Table VI.

TABLE III. RESULTS OF LOADING PILES WITH LENGTH OF 8,10 AND 12 METERS AND INTERVALS OF 1, 1/5 AND 2 METERS.

\begin{tabular}{|c|c|c|c|c|c|c|c|}
\hline Pile Group & $\begin{array}{l}\text { Ratio of the } \\
\text { distance to } \\
\text { the Piles }\end{array}$ & $\begin{array}{c}\text { Maximum } \\
\text { Subsidence of } \\
\text { the Pile } \\
\text { Group }(\mathrm{m})\end{array}$ & $\begin{array}{l}\text { Ultimate } \\
\text { Bearing } \\
\text { Capacity } \\
\mathrm{KN} / \mathrm{m}^{2}\end{array}$ & $\begin{array}{l}\text { Total } \\
\text { Stress } \\
\text { KN/m }\end{array}$ & $\begin{array}{c}\text { Shear } \\
\text { Strain of } \\
\text { the Soil } \\
\%\end{array}$ & $\begin{array}{c}\text { Shear Bulk } \\
\text { of the Soil } \\
\%\end{array}$ & $\begin{array}{c}\text { Normal } \\
\text { Effective Stress } \\
\text { of the Pile } \\
\mathrm{KN} / \mathrm{m}\end{array}$ \\
\hline Length of $8 \mathrm{~m}$ and Distance of $1 \mathrm{~m}$ & 8 & 1.33 & 1334 & 8590 & 65.11 & 44.73 & 639.34 \\
\hline Length of $8 \mathrm{~m}$ and Distance of $1.5 \mathrm{~m}$ & 5.33 & 1.27 & 1305 & 9230 & 54.58 & 40.47 & 728.1 \\
\hline Length of $8 \mathrm{~m}$ and Distance of $2 \mathrm{~m}$ & 4 & 1.03 & 1139 & 11360 & 35.70 & 32.36 & 677.18 \\
\hline Length of $10 \mathrm{~m}$ and Distance of $1 \mathrm{~m}$ & 10 & 2.31 & 2088 & 16160 & 160.85 & 79.85 & 1000 \\
\hline Length of $10 \mathrm{~m}$ and Distance of $1.5 \mathrm{~m}$ & 6.67 & 2.21 & 2099 & 17930 & 123.90 & 74.99 & 1100 \\
\hline Length of $10 \mathrm{~m}$ and Distance of $2 \mathrm{~m}$ & 5 & 2.08 & 1959 & 15440 & 74.49 & 68.98 & 1130 \\
\hline Length of $12 \mathrm{~m}$ and Distance of $1 \mathrm{~m}$ & 12 & 1.36 & 1474 & 12860 & 91.07 & 54.83 & 633.5 \\
\hline Length of $12 \mathrm{~m}$ and Distance of $1.5 \mathrm{~m}$ & 8 & 1.37 & 1702 & 18120 & 83.24 & 43.18 & 833.61 \\
\hline Length of $12 \mathrm{~m}$ and Distance of $2 \mathrm{~m}$ & 6 & 1.5 & 1535 & 14540 & 65.39 & 39.75 & 665.78 \\
\hline
\end{tabular}

TABLE IV. THE RESULTS OF LOADING A PILE GROUP WITH LENGTH OF 10 METERS AND INTERVAL OF 1/25 METERS

\begin{tabular}{|c|c|c|c|c|c|c|}
\hline $\begin{array}{l}\text { Normal } \\
\text { Effective } \\
\text { Stress of } \\
\text { the Piles }\end{array}$ & $\begin{array}{c}\text { Soil } \\
\text { Bulk } \\
\text { Strain } \\
\%\end{array}$ & $\begin{array}{c}\text { Shear } \\
\text { Strain } \\
\text { of the } \\
\text { Soil } \\
\text { Mass } \\
\%\end{array}$ & $\begin{array}{l}\text { Total } \\
\text { Stress } \\
\text { KN/m }\end{array}$ & $\begin{array}{c}\text { Ultimate } \\
\text { Bearing } \\
\text { Capacity } \\
\text { KN/m2 }\end{array}$ & $\begin{array}{c}\text { Maximum } \\
\text { Subsidence } \\
\text { of the Pile } \\
\text { Group } \\
\text { m }\end{array}$ & $\begin{array}{l}\text { Ratio of } \\
\text { the } \\
\text { Length } \\
\text { to the } \\
\text { Intervals } \\
\text { of the } \\
\text { Piles }\end{array}$ \\
\hline 1080 & 78.70 & 91.65 & 16820 & 2114 & 2.31 & 8 \\
\hline
\end{tabular}

TABLE V. THE RESULTS OF LOADING A PILE GROUP WITH LENGTHS OF 8 METERS AND INTERVALS OF 0/5 METERS

\begin{tabular}{|c|c|c|c|c|c|c|}
\hline $\begin{array}{c}\text { Normal } \\
\text { Effective } \\
\text { Stress of } \\
\text { the Piles } \\
\mathrm{KN} / \mathrm{m}\end{array}$ & $\begin{array}{c}\text { Soil } \\
\text { Bulk } \\
\text { Strain } \\
\%\end{array}$ & $\begin{array}{c}\text { Shear } \\
\text { Strain } \\
\text { of the } \\
\text { Soil } \\
\text { Mass } \\
\%\end{array}$ & $\begin{array}{l}\text { Total } \\
\text { Stress } \\
\mathrm{KN} / \mathrm{m}\end{array}$ & $\begin{array}{c}\text { Ultimate } \\
\text { Bearing } \\
\text { Capacity } \\
\mathrm{KN} / \mathrm{m}^{2}\end{array}$ & $\begin{array}{c}\text { Maximum } \\
\text { Subsidence } \\
\text { of the Pile } \\
\text { Group } \\
\text { m }\end{array}$ & $\begin{array}{l}\text { Ratio of } \\
\text { the } \\
\text { Length } \\
\text { to the } \\
\text { Intervals } \\
\text { of the } \\
\text { Piles }\end{array}$ \\
\hline 629.16 & 48.48 & 47.47 & 7110 & 1264 & 1.29 & 16 \\
\hline
\end{tabular}

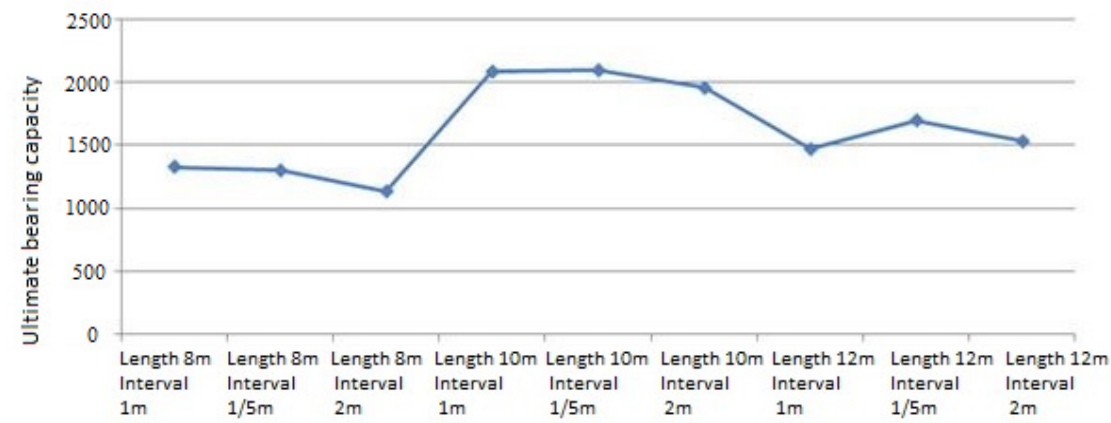

Fig. 2. Bearing capacity of pile groups shift with 8,10 and 12 meters and distances of $1,5.1$ and 2 meters. 
TABLE VI. THE RESULTS OF LOADING A PILE GROUP WITH INCLINED LATERAL PILES AND ANGLES OF 0, 15, 30 AND 45 DEGREES.

\begin{tabular}{|c|c|c|c|c|c|c|c|c|}
\hline $\begin{array}{c}\text { Bending } \\
\text { Moment of } \\
\text { Kn } / \mathrm{m}\end{array}$ & $\begin{array}{c}\text { Shear Stress } \\
\text { of Middle } \\
\text { Piles } \\
\mathrm{KN} / \mathrm{m}\end{array}$ & $\begin{array}{c}\text { Axial Force of } \\
\text { Middle Piles } \\
\mathrm{KN} / \mathrm{m}\end{array}$ & $\begin{array}{c}\text { Bending } \\
\text { Moment of } \\
\text { Lateral Piles } \\
\mathrm{KN} / \mathrm{m}\end{array}$ & $\begin{array}{c}\text { Shear Stress } \\
\text { of Lateral } \\
\text { Piles } \\
\mathrm{KN} / \mathrm{m}\end{array}$ & $\begin{array}{c}\text { Axial Force of } \\
\text { Lateral Piles } \\
\mathrm{KN} / \mathrm{m}\end{array}$ & $\begin{array}{c}\text { Total Stress of } \\
\text { the Pile Group } \\
\mathrm{KN} / \mathrm{m}\end{array}$ & $\begin{array}{c}\text { Ultimate } \\
\text { Bearing } \\
\text { Capacity } \\
\mathrm{KN} / \mathrm{m}^{2}\end{array}$ & $\begin{array}{c}\text { Maximum } \\
\begin{array}{c}\text { Subsidence of } \\
\text { the Pile Group } \\
\mathrm{m}\end{array}\end{array}$ \\
\hline 262.99 & 103.7 & 2090 & 1560 & 962.17 & 2170 & 3620 & 1245 & 0.6 \\
\hline 1330 & 820.55 & 3440 & 1560 & 1780 & 2460 & 5390 & 1860 & 0.86 \\
\hline 6050 & 4920 & 9870 & 64800 & 13190 & 6260 & 13220 & 6625 & 2.46 \\
\hline 7570 & 5610 & 9690 & 77000 & 15910 & 6880 & 10330 & 7645 & 2.32 \\
\hline
\end{tabular}
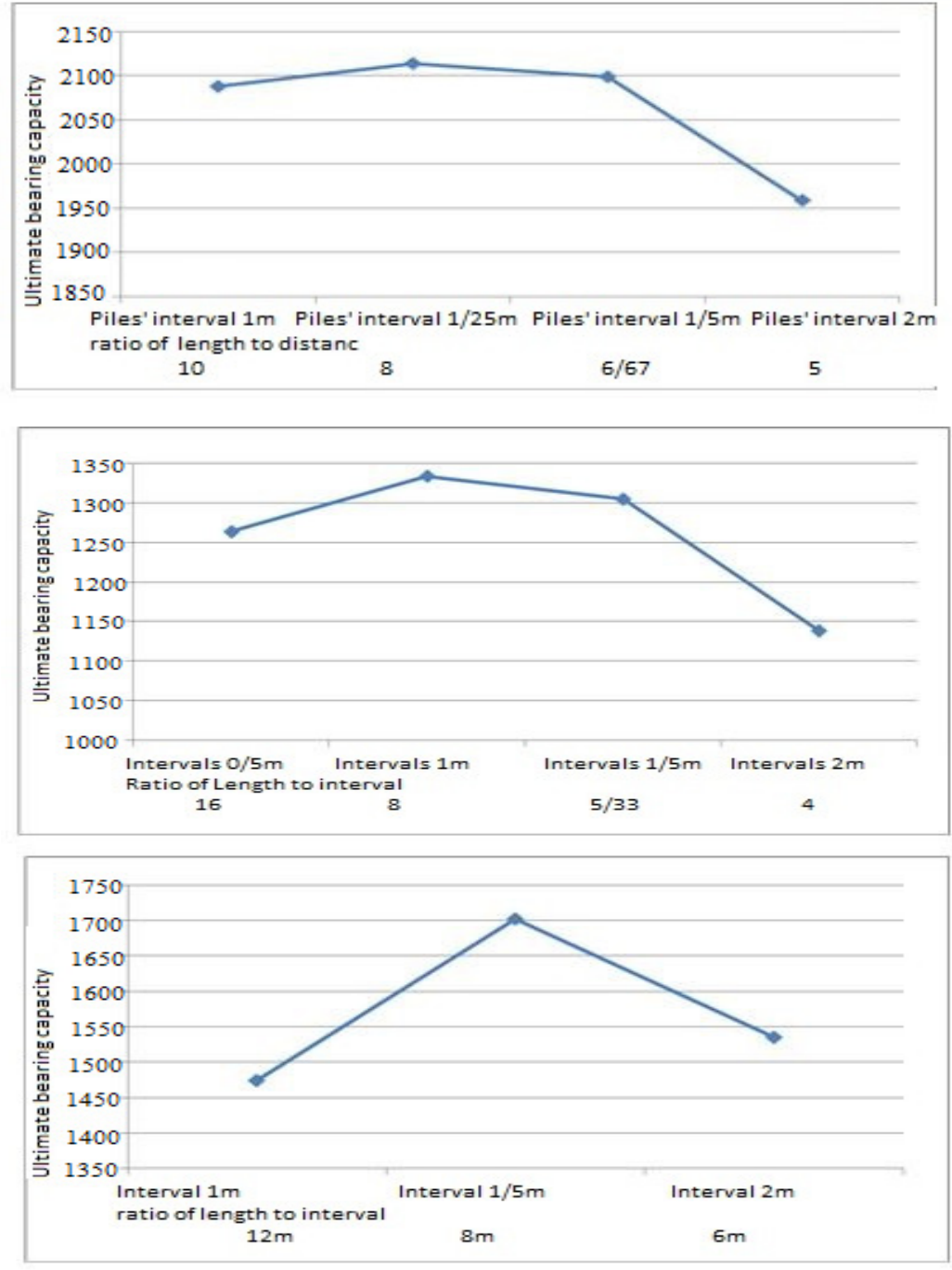

Fig. 3. Plot of ultimate bearing capacity of pile groups in different lengths and intervals
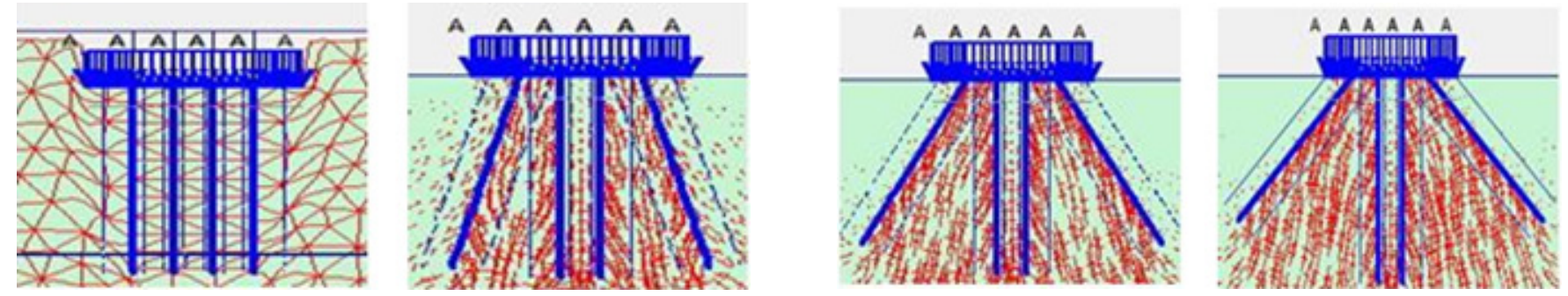

Fig. 4. Pile groups with 10 meters length, $1 / 25$ meters of interval and $0,15,30,45$ degrees of angles 


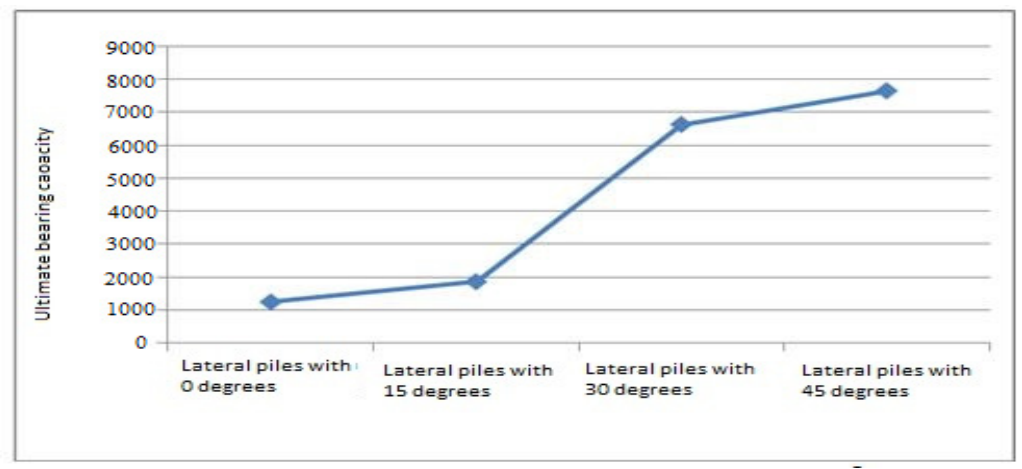

Fig. 5. A plot for ultimate bearing capacity

Results show that with increasing the angles of the lateral piles in contrast with vertical axis, the ultimate bearing capacity of the pile increases dramatically. In the pile groups with 45 degrees of inclination, ultimate bearing capacity reaches its maximum value which is about 6 times the ultimate bearing capacity of lateral vertical piles. Also the results showed that the middle piles are more forceful than the lateral piles, but shear stress and bending moment of the lateral piles were much greater compared to the middle piles'.

\section{DiscUSSION}

Three-dimensional models were built in three groups with lengths of 8,10 and 12 meters and were loaded under axial loading until the failure of the soil mass. The ultimate bearing capacity of each pile group was acquired. The uploading results are summarized below.

\section{A. $\quad$ Piles with length of 8 meters}

Four models with intervals of $0 / 5,1,1 / 5$ and 2 meters were considered. By reducing the ratio of length to interval the pile's ultimate capacity decreased, thus it means by increasing the piles' intervals, the ultimate bearing capacity would be reduced. The highest bearing capacity of the group obtained at intervals of one meter. Also by increasing the piles' intervals, the amount of groups' subsidence reduced with regard to reduction in the bearing capacity, which is of course due to the reduction of the applied load. Soil's shear strain and bulk strain are reduced by increasing the piles' intervals, due to the significant increase in the volume of the soil mass. With an increase in the volume of the soil between the piles, as defined in strain relationship, shear strains and bulk would reduce.

\section{B. Piles with length of 10 meters}

Four models with intervals of $1,1 / 25,1 / 5$ and 2 meters were constructed in this group. At first hand by reducing the ratio of length to interval from 10 to 8 the pile's ultimate capacity increased, then by another drop of this ratio, the ultimate bearing capacity was reduced. The highest bearing capacity of the group obtained at intervals of $1 / 25$ meters. It shows that the maximum bearing capacity of the group was obtained at a ratio of 8 . Also increasing the intervals, group's subsidence would decrease with reduction in the loading capacity. Soil's shear strain and bulk strain were reduced by increasing the piles' intervals, due to the significant increase in the volume of the soil mass.

\section{Piles with length of 12 meters}

Three models with intervals of $1,1 / 5$ and 2 meters were constructed in this group. By reducing the ratio of length to interval from 12 to 8 in this group the pile's ultimate capacity increased, however by another drop, the ultimate bearing capacity would reduce. The highest bearing capacity of the group was obtained at intervals of $1 / 5$ meters. It shows that the maximum bearing capacity of the group was obtained at a ratio of 8 . Also, increasing the intervals, group's subsidence would decrease with a reduction in bearing capacity. Soil's shear strain and bulk strain are reduced by increasing the piles' intervals.

\section{D. $2 d$ model}

The model with the maximum ultimate bearing capacity from the three-dimensional analysis was selected and modeled as a row of 4 piles in Plaxis 2D. Then, by varying the angles of the piles, the impact of inclined piles on the bearing capacity of the pile group was investigated. Results showed that by increasing the loading angle to the vertical axis, the ultimate bearing capacity dramatically increases. The ultimate bearing capacity reaches its maximum value in the pile group of piles with 45 degrees, which is about 6 times the ultimate bearing capacity of lateral vertical piles. This can be attributed to the fact that when the pile applies upright, the bearing capacity achieves only through the pile toe's resistance and pile shaft's resistance. When an inclined pile with length of 1 was implemented, in addition to the resistance of tip and sidewalls, downward component of the pile's axial force (from the inclined piles' share), is equal to $1 \sin \alpha$, which applies to the soil beneath the pile. This means that the greater the inclination angle, the greater the force. In other words part of pile's force transfers to the soil under the pile and so, pile can bear more loads and eventually its bearing capacity increases.

\section{CONCLUSION}

The exact layout of piles used in deep foundations has a direct effect on constructional costs. Thus, determining an optimal layout is of significant importance. However, a variety of factors are to be considered. 3D and 2D modeling, using 
finite element software, was employed in this paper to assess different pile layouts on granular soil. Different models were employed to investigate the effect of length, slope and distance between piles. The different steps of the analysis are presented and Results are further discussed.

\section{REFERENCES}

[1] R. Noorzad, G. R. Saghaee, "Seismic Analysis of Inclined Micropiles Using Numerical Method", International Foundation Congress and Equipment Expo, Orlando, Florida, United States, March 15-19, 2009

[2] I. Juran, A. Benslimane, S. Hanna, "Engineering analysis of dynamic behavior of micropile systems", Transportation Research Record: Journal of the Transportation Research Board, Vol. 1772, pp. 91-106, 2001

[3] B. B. Jafar, R. Ahmad, "Optimize the Configuration of Piles Group with Genetic Algorithm Under Asymmetric Loading", 6th National Conferences of Civil Engineering, Semnan, Iran, 25 April 2011

[4] M. J. Tomlinson, J. Woodward, Pile Design and Construction Practice, 6th edition, CRC Press, 2014

[5] J. B. Kim, R. J. Brungraber, "Full-scale lateral load tests of pile groups", ASCE Journal of the Geotechnical Engineering Divission, Vol. 102, No. GTI, pp. 87-105, 1976
[6] H. Niandou, D. Breysse, "Reliability Analysis of a Piled Raft Accounting for Soil Horizontal Variability", Computers and Geotechnics, Vol. 34, pp. 71-80, 2007

[7] N. Gerolymos, A. Giannakou, I. Anastasopoulos, G. Gazetas, "Evidence of beneficial role of inclined piles: observations and Summary of numerical Analyses", Bulletin of Earthquake Engineering, Vol. 6, No. 4, pp. $705-722,2008$

[8] E. M. Comodromos, C. T. Anagnostopoulos, M. K. Georgiadis, "Numerical assessment of axial pile group response based on load test", Journal of Computers and Geotechnics, Vol. 30, pp. 505-515, 2003

[9] S. Rajashree, T. Sitharam, "Nonlinear Finite-Element Modeling of Batter Piles under Lateral Load", ASCE J. Geotech. Geoenviron. Eng., Vol. 127, No. 7(604), pp. 604-612, 2001

[10] H. Poulos, E. Davis, Pile foundation analysis and design, John Wiley and Sons, 1980

[11] G. Ranjan, G. Ramasamy, R. P. Tyagi, "Lateral response of batter piles and pile bents in clay," Indian Geotech. J., No. 10, No. 2, pp. 135-142, 1980

[12] A. Hanna, A. Afram. "Pullout capacity of single batter piles in sand”, Can. Geotech. J., Vol. 23, No. 3, pp. 387-392, 1986

[13] A. Hanna, T. Nguyen, "Shaft resistance of single vertical and batter piles driven in sand." ASCE Journal of Geotechnical and Geoenvironmental Engineering, No. 129, pp. 601-607, 2003 